\title{
7 Anti-labour repression in the in-between spaces of empire
}

\author{
The Compagnie des Messageries \\ Maritimes and the steamship workers \\ of the "China Line" (1900-20)
}

\section{Charles Bégué Fawell}

In the lore of labour history, strikes in ports were won or lost depending on whether the ships departed. If the ships stayed in port, the workers had succeeded; if the ships set out, the bosses had prevailed. But this narrative of labour contests lacks in nuance what it possesses in drama. After all, even when the most massive strikes broke out, many ships were already at sea. On ships at sea, moreover, outbursts of labour militancy could occur without instructions from home. Perhaps unsurprisingly, then, while the historiography of late nineteenth- and early twentieth-century labour movements in France includes comprehensive accounts of battles over the docks of major port cities like Marseille or Le Havre, far less is known about how Belle Époque struggles over labour unfolded outside the dockyards of metropolitan ports; that is, at sea, in motion and beyond the oversight of metropolitan port authorities. ${ }^{1}$

Syndicalism in France's maritime industries began in the 1870s, but mass actions culminated in the opening decades of the twentieth century. In Marseille, France's "gateway to the Orient", the new century ushered in a wave of massive strikes; first in 1900, then again in 1902, 1907 and 1912, after which tensions were contained during the First World War, only to explode with renewed intensity as the war concluded. ${ }^{2}$ None of these labour conflicts was put on hold when the worksite was mobile and far from home. How, then, did shipping companies combat labour militancy in transit, far from European ports, along maritime highways?

The scarcity of responses to that question reflects, in part, scholarly assumptions regarding transit and the spaces in which it occurs. Though repeated "global turns" and "mobilities" paradigms have emphasised the importance of connectedness and the mobile subject, most scholarship continues to address the transoceanic routes connecting imperial metropoles to far-off colonies in functionalist terms, with the infrastructure of maritime routes appearing as a conveyor belt that neutrally connects port to port, as if node to node. ${ }^{3}$ By implication, maritime highways come across as depoliticised and un-peopled - quintessential spaces, as opposed to places. ${ }^{4}$ And yet, as this chapter suggests, maritime routes were far more crowded and contested than residual assumptions suggest. Critical arenas for the struggle over labour militancy that gripped Europe in its Belle 
Époque, shipping corridors were neither neutral infrastructure nor homogenous expanses. Rather, these in-between spaces of empires were shaped by competing legal regimes, shifting borders and the complex interplay of people, ship, sea and port. ${ }^{5}$

Foraying into the question of how shipping companies combatted labour militancy in motion, this chapter focuses on France's largest shipping company on Europe-to-Asia routes, the Compagnie des Messageries Maritimes, and specifically its "China Line", an intercontinental route that began in Marseille, crossed the Suez Canal and extended (despite its name) to the Japanese port of Yokohama. ${ }^{6}$ In the early twentieth century, the Messageries Maritimes experimented with a range of tactics to prevent labour militancy from spreading across this bustling and geopolitically vital highway, and to quash strikes when they arose en route. The company systematically labelled strikes as "mutinies", manned ships with scab crews and mobilised consuls and police forces in foreign layover ports. Simultaneously, the Messageries tacked between the French agencies historically tasked with regulating the merchant marine, and the Navy, which offered ship captains and company agents the tantalising possibility of meeting labour unrest with martial justice.

The efficacy of those tactics, however, depended on whether Messageries bosses in Marseille, ship captains at sea and company agents stationed along the route could outmanoeuvre workers in the interstices of imperial sovereignty and the politics of transoceanic, trans-imperial transit. In such contests, I argue, workers proved surprisingly capable of foiling company plans. The Messageries' ensemble of tactics thus amounted to little more than a strategy of opportunism with one important exception. In developing a global system to recruit and circulate African and Asian workers, the Messageries found a structural, as opposed to opportunistic, approach to thwarting labour militancy within its mobile workforce; outsourcing avant la lettre. ${ }^{7}$

To begin, it is worth reflecting on the Messageries Maritimes' origins and its orientation at the turn of the twentieth century. ${ }^{8}$ Among French companies, the Messageries was rivalled only by the famed Compagnie Générale Transatlantique, which, as the name suggests, dominated France's trans-Atlantic traffic, while leaving what lay "East of Suez" in the hands of the Messageries. Internationally, the Messageries spent the latter nineteenth-century trying to keep up with its perennial rival for Europe-to-Asia traffic, the British Empire's Peninsular \& Oriental Company $(P \& O)$. However, competition was stiff enough that the lines reached an early "Gentleman's Agreement", alternating their schedules and sharing the lucrative market for trans-Suez cargo and passengers. ${ }^{9}$ Secure in its market, the Messageries expanded, and by 1891 the company was transporting over 120,000 passengers annually on a fleet of 62 ships (most of them built in the shipyards of La Ciotat, near Marseille). ${ }^{10}$ After the First World War devastated its fleet, the Messageries struggled to withstand challenges from the subsidised shipping lines of Germany, Japan and others. Nonetheless, France's commercial proxy "beyond Suez" remained a giant of the Age of Steam, with one of the world's largest fleets and a global network of agencies and facilities. ${ }^{11}$ 
Like the British $P \& O$, the Messageries was privately owned but intertwined with the operations of the imperial state. From 1881 on, the French state subsidised ship construction and some of the operational costs of voyages, while the company, in turn, carried mail to the far corners of the French Empire, along with soldiers, administrators and bureaucrats, diplomats and statesmen - essentially anyone and anything the state told it to transport. Those soldiers, administrators and diplomats travelled alongside tourists, migrants, convicts, entertainers, merchants, missionaries and of course, ship workers, who, on the largest of these ships, lived by the hundreds. Certain Messageries ships were specialised for cargo, and others for passengers, but the boundaries between freight and voyagers - and between private commerce and imperial affairs - were anything but clear. As Jules Verne famously observed in a best-selling book of the 1870 s, the nineteenth-century steamship was evolving into nothing less than a "floating city". ${ }^{12}$ What, then, could a company like the Messageries do when "floating cities" became labour battlegrounds?

\section{Makeshift solutions: the mutiny accusation and "makeshift crews"}

Nomenclature was the first arena in which navigation companies responded to surging labour militancy at sea. To label the intensifying contestation of maritime workers, ship captains and company officials returned to an ancient concept: mutiny. Unlike the legendary "Mutiny on the Bounty" and other precedents from the Age of Sail, though, mutiny in the era of labour militancy did not entail commandeering a ship or capturing a captain. Nor were these mutinies equivalent to the naval uprisings of the First World War and its aftermath, when state-paid sailors contested their governments en masse. Rather, aboard the large steamships of the turn-of-the-century, militancy became mutinous when it stopped traffic, throwing a wrench into the giant assembly line of global trade that had developed in the wake of steam navigation and the Suez Canal. In the eyes of pro-business diplomats and jurists, a mutiny was merely a strike in motion, and to take the ship captains of the Age of Steam at their word, the period abounded with mutinies. Indeed, the legal threshold for such a qualification was remarkably low, for as soon as multiple crewmembers refused a direct order from their captain, they were engaging in mutinous activity. ${ }^{13}$ In choosing not to differentiate between violent and non-violent acts of resistance, captains and their sympathisers used the mutiny accusation ("revolt" was also a common label) to suggest that insubordination was violence. As will be seen, however, the myriad actors who were pulled into labour negotiations en route - consuls, port police and foreign jurists were not always as quick to conflate protest and mutiny.

Beyond rhetorical framing, the Messageries developed a range of concrete practices of intervention. Perhaps the most obvious tool for preventing the spread of militancy to the route was to recruit a "makeshift" (i.e. scab) crew. ${ }^{14}$ Normally, crews had to be drawn mostly from the Inscription maritime, or Maritime registry, a centuries-old institution that served as a state registry of professional sailors. 
During strikes, the Messageries was sometimes allowed to forgo the registry, instead manning its ships with unscreened applicants from Marseille's streets, or even navy men (when available). This tactic offered shippers an efficient means of sidestepping strikes, but it had glaring defects, for while the Messageries could slip a makeshift crew across the picket line and onto a ship, once that ship was en route, all bets were off.

A 1909 voyage of the Messageries ship, Calédonien, running the China Line from Marseille to Yokohama, illustrates the potential volatility of makeshift crews. In voyage reports, the captain of the Calédonien noted that his makeshift crew had performed well until laying over at Port-Saï, the chokepoint of maritime traffic at the head of the Suez Canal, where they encountered another Messageries ship, this one carrying a full crew of inscrits maritimes, or registered (i.e. professional) sailors. In front of a crowd of foreign ships, the Calédonien endured an extended barrage of insults and menaces from its sister ship. ${ }^{15}$ In a vacuum, the bloodless clash might have been of little consequence, but the route and its ports were not vacuums, so much as they were international stages. ${ }^{16}$ For the Messageries, which was locked in intense and increasingly mediatised competition with other nationally subsidised lines (not to mention a near-constant public relations campaign within France to maintain government subsidies), public humiliation had real consequences. Calling the incident "a demonstration of savages attended by foreign ships", the captain and his directors declared it a significant setback in their struggle with labour; not, of course, because of the injured pride of their makeshift crew, but rather because the militant sailors encountered by the Calédonien had used the most crowded section of the China Line to castigate the company, exposing both its internal divisions and its reliance on underqualified sailors. The public spectacle rendered the company vulnerable to reports of instability within their ranks - reports that could rattle around the press, compromise the line's appeal to wealthy passengers and shake the resolve of critical allies within the French government. ${ }^{17}$

In 1912, against the backdrop of Marseille's most intense strike to date, a subsequent captain of the Calédonien discovered that hiring makeshift crews could backfire even without an external shock. Once again exempted from the maritime registry, the Messageries had manned its ship with a makeshift crew, sending it out for the roughly 80-day journey to Yokohama and back. Midway, however, labour relations broke down, thefts became rampant and the Calédonien's officers discovered to their horror that the crew was sabotaging their ship. To his directors, the captain complained that his makeshift crew were "veritable apaches", using a term that evoked the infamous street gangs of Belle Époque Paris. ${ }^{18}$ To make matters worse, faced with what he termed a "revolt" and a "mutiny" from the very men who were supposed to be quashing revolts and mutinies, he found himself powerless to react. When conflict spiked en route to their layover in Singapore, for instance, he noted:

I waited by as long as I could, and I even ceded in Singapore when they refused to serve in front of the Consul, so that the passengers could have no 
doubt that we were dealing with a crew of apaches, and because we were in foreign land, and it would have had a very poor effect to show that we were working with an undisciplined crew, recognizing no authority at all, and, on the contrary, in a state of revolt. ${ }^{19}$

As the incidents suggested, the company could wrangle its way into recruiting a makeshift crew to keep the China Line moving, but once in motion, there was no guarantee that the crew would obey orders.

The reproachful gaze of passengers and foreign commentators, meanwhile, constrained the company's ability to punish rebellious workers.

\section{Cops, consuls and the interstices of imperial jurisdictions}

Makeshift crews may have been, to the Messageries, an infuriatingly unreliable means of clearing labour militancy from the route, but other resources were available to captains and company agents. Every layover port on the China Line had a French consul, for instance, whose pro-company sympathies and direct lines to port police made them compelling allies in anti-labour operations. Again, though, voyage reports of the Messageries reveal the limits of calling in consuls and cops to crack down on mutinous workers. ${ }^{20}$ Often enough, campaigns to mobilise consular networks and port police became mired in uncertainty over the jurisdictional boundaries between localities and foreign ships. Likewise, determining when a strike, or mutiny, had become disruptive enough to threaten security proved surprisingly thorny. For one of many examples in which anti-labour crackdowns idled in the interstices of imperial sovereignty, let us return to the Calédonien, which set out for East Asia in 1913 with a new crew and captain, only to endure another unpunished mutiny, despite the total sympathy of a French consul and the proximity of port police.

As reams of reports relate, the mutiny broke out in the Indian Ocean, shortly before the Calédonien reached its scheduled layover in British Colombo, Ceylon (today's Sri Lanka). ${ }^{21}$ Tensions crystallised dramatically when, just after the decision had been made to halt work, a crewmember succumbed to typhoid fever. Instead of carrying out the burial at sea, as rules prescribed, the workers stood still, turning the rotting corpse into a sanitary time bomb and forcing the ship's officers to carry out the morbid labour themselves. After the showdown, the ship limped into Colombo's port, where officers promptly called on the French consul to avenge the insult and injury. Consular support was beyond doubt, since it turned out that France's official representative held two roles at once: consul, and general agent of the Messageries in Ceylon. Disgusted by the collapse of discipline aboard the ship, this consul and company man summoned the port police, only to find that they refused to board the ship out of fear of legal complications. The police, he learnt, would limit themselves to returning "deserting" sailors to the ship. Ironically, by ensuring that no one abandoned the action, this measure reinforced the strikers' cohesion.

As authorities searched for a silver bullet, Colombo's press began to criticise the company over its idling ship. Increasingly hot under the gaze of the press 
and ships of foreign competitors, and lacking means of repression, one officer summarised the situation simply: "We were completely disarmed". In what the consul would describe as a total "abdication of the principle of authority", the officers conceded to crew demands, crippling the case they could subsequently bring against the sailors. The ship carried on until it reached the next layover, in the French colonial port of Saigon, where an inquiry was conducted. Having tightened ranks during the week's journey between Colombo and Saigon, however, the crew refused to identify ringleaders. ${ }^{22}$ Mobility and immobility alike had played to the workers' favour as they successfully navigated maritime borderlands.

While the Messageries and its sympathisers may have been disheartened by the lack of support from British authorities in Colombo, it should have come as no surprise. Trans-Suez routes were full of layovers at British ports, and this geopolitical predicament placed the Messageries at the mercy of a government which, again and again, refused to clarify its policy regarding intervention onboard foreign vessels. Seven years before the Calédonien's officers were forced into their humiliating "abdication of the principle of authority" in Colombo, for instance, a Russian ship laying over in the South Asian port met a similar fate, sparking a legal debate among British authorities that exposed the ambiguities of mutiny in the age of labour militancy, and sovereignty in the in-between spaces of empires.

In spring of 1906, the Grigory Moerch pulled into Colombo's harbour with a cargo of petroleum for what appeared to be a routine layover on the ship's long voyage to Vladivostok. A desperate cable to the Russian consul shattered the illusion of mundanity. The crew, it warned, "was mutinous and the Captain's life was in danger". ${ }^{23}$ As it turned out, the Russian consul was not Russian at all, for the position had been recently delegated to the French Consul. A French consul negotiating with British colonial officials over the fate of a Russian crew may sound exceptionally complicated, but it was not even the only international knot tying up the China Line at that moment; at the exact same moment in Naples, for instance, a few layovers westward, British, Italian and Chinese state officials were negotiating the fate of a British ship and its mutinous Chinese crew. ${ }^{24}$ In Colombo, the French-turned-Russian consul promptly requested that police board the ship, "strictly", he insisted, "to protect the Captain from violence". The crew, however, wisely refrained from provoking the police guard, and when the consul and captain sought a mass arrest of the crew, they were denied by Ceylon's attorney general. Faced with a peaceful mutiny, the police guard withdrew. As he explained to superiors in London, the attorney general would not authorise a crackdown unless the harbour's security was threatened or violence occurred on board, and while he suspected there had been threats of violence, he had to admit, "But here we have no threat, only a strike, and with that we cannot interfere on a Foreign ship". ${ }^{25}$ His colleague was less circumspect: "The Consul is anxious to force the crew . . ashore, but this is no business of ours". ${ }^{26}$

Floating in Colombo's harbour, the Grigory Moerch's engine remained silent and the sailors refused to budge. Inside Colombo, meanwhile the ship's officers and consul continued to lobby for repression, after which the captain planned to 
replace his rebellious countrymen with a "native crew". Eventually, they procured a warrant to arrest the entire crew, only to watch the attorney general revoke it at the last moment. With internal divisions growing and the local press speculating on the standoff, port authorities hatched a plan to tow the petroleum ship outside of Colombo's harbour and abandon its crew to their fate. At last, just before the operation launched, an offer of back pay and safe passage to Russia reached the crew, who accepted, coming ashore and ending the strike.

If the facts of the episode were straightforward enough, its legal implications were practically indecipherable. Embarrassed by the confusion that had reigned throughout the standoff, British authorities in Ceylon wrote to London requesting legal precedents to answer two seemingly simple questions: did a colonial government have "legal power to interfere by coercive action in the event of a difficulty, not involving a breach of the peace, arising between the Master and crew of a foreign ship lying in harbour", and if so, how far would they be "authorized in arresting mutineers on board a foreign ship when requested to do so by a Captain of the ship and the Consul of the State to which the ship belongs?"27 Unfortunately for them, historical precedent merely multiplied the questions. The last Russian ship to run into labour disputes in British waters, for instance, was thought to have been boarded forcibly by the police, yet there existed no administrative record of the invasion whatsoever, raising the troubling spectre of extra-legal operations. ${ }^{28}$ As the legal debate climbed to the Foreign Office, moreover, it became tangled in a web of complicating factors. Binational treaties seemed to clash with municipal codes, while scholars of international law disagreed over whether local law and ship law were concurrent or mutually exclusive. Commentators contradicted each other over whether crimes committed by crewmembers at sea became null once in harbour, while others cautioned that cases against crewmembers would crumble if crimes were tried on land after being tried at sea. Different rules applied to a merchant vessel and a "man-of-war", yet few could say with clarity what to do when a merchant vessel was carrying military materiel or had been contracted by a foreign state. Having "searched in vain for a decided case", Ceylon's attorney general threw up his hands. ${ }^{29}$

Their questions answered with a cacophony of interpretations and precedents, British authorities settled on a policy of ambiguity. Physical crackdowns would be authorised only when the British port in question was threatened, or violence was occurring on-board a foreign ship. Shrewdly, though, no one supplied a basic definition of what constituted a threat to port security, or when violence "breached the peace". China Line shippers, then, faced a dilemma: the worker "mutinies" occurring along the route were sufficiently severe to force a state-backed company to the table, yet insufficiently bloody to trigger intervention by foreign port police. On the China Line, "foreign" almost invariably meant British, and the British government was far from confident that intervening in labour disputes aboard foreign ships was lawful, or in its interest. Asked to choose between their right to monopolise violence on British territory and their responsibility to act as the unpaid muscle for any foreign ship that steamed into port with a mutinous crew, British authorities declined to choose at all. 


\section{Sovereigns of the route}

Faced with the reality that even the most sympathetic French consul could not guarantee a police response to labour militancy along the route, Messageries bosses might simply have steered ship captains to French ports, where police were unburdened by fears of sovereign violations. While the British were hegemons "East of Suez", French captains belonged to an empire with a host of territories around the Indian Ocean and South China Sea, many possessing ports that could serve as bases for coordinating anti-labour reprisals: Djibouti, on the Red Sea; Madagascar, Réunion and a constellation of smaller Indian Ocean islands; coastal enclaves in India and China; and most importantly, Indochina, whose ports were becoming critical nodes of the empire's Indian and Pacific Ocean traffic. Yet, from the company's perspective, even French territory provided a shaky foundation for exerting authority over militant labour. After all, while company agents could call French police, their workers could appeal to the aged and complex institution of the Inscription maritime (Maritime registry).

Founded in the late seventeenth century, the Inscription maritime emerged to replace press gangs with a registered maritime workforce that could sustain trade routes and fill the ranks of the royal navy in times of crisis. Despite its royal pedigree, the institution survived the revolution, but its reaffirmation in revolutionary law came with a crucial caveat transferring the power to punish sailors from captains and admiralty courts to common law tribunes. This principle of equality under the law was undermined by reforms of the Second Empire (185270), which reasserted a special legal regime for sailors of the Inscription and re-empowered captains to act as judge and jury. In 1896, however, captains were again stripped of some of these coercive powers, and the disciplinary code for sailors was again open to debate and interpretation. ${ }^{30}$ Among the 100,000-plus workers who populated France's Inscription in 1900, few could say with certainty where the institution would place its weight in the coming struggles over labour rights. On the one hand, the Inscription tied sailors to a special penal code in which they might be hurled in prison for work infractions or accused of desertion if they abandoned their worksite at the wrong moment. On the other hand, the Inscription existed to ensure that France would always have a body of professional sailors available in times of crisis, meaning that it was less concerned with the profits and pride of shipping magnates than with preventing sailors from fleeing their line of work. Whether merchant mariners could count on an institutional champion in the state, at the very least they would have an arbiter. ${ }^{31}$

By 1900, as Marseille's era of massive strikes began, this spectre of state arbitration horrified ship captains, who believed that their authority was under siege and that only new allies in the French state could save them. As one captain put it in 1900, "The situation has become all too clear. 1) They have made sure to disarm the Captains totally. 2) Punishment by disembarkment is illusory today. 3) By order, the Consuls are disarmed" ${ }^{32}$ His despair was understandable. Having faced a rebellious crew for weeks, he had failed to punish them in the Japanese port of Yokohama, the terminus of the China Line, where an attempt to dissuade striking sailors with a combination of consular orders and police interventions had totally 
missed the mark (like their British counterparts, it seems Japanese authorities preferred sending labour disputes down the line over clogging their courts with the problems of foreigners). Then, during a homebound layover in French Saigon, the captain appealed to the Inscription, only to watch its magistrate grant the accused sailors the right to a trial on metropolitan soil in their homeport of Marseille, a month's journey away. As a result, the sailors who had contested this captain's sovereignty were able to, as he put it, "rejoice in the most perfect impunity for six weeks" - ample time to craft a legal defence, jump ship or foment anger among fellow workers. ${ }^{33}$ To company directors, the captain named the last weapon in his arsenal, writing, "What remains are the warships - in the future, when punishments are called for, and there will be no shortage of that, I am going to address myself solely to the warships and that will do it". ${ }^{34}$

Writing nine years later, after multiple strikes had rocked the maritime sector, another captain from the China Line drew a similar picture. This time, however, he called not only for the Messageries to rely on Navy justice, but to deploy the Navy in an institutional attack against the Inscription. Thanks to the pervasive influence of "strike-spreaders [gréviculteurs], saboteurs and others", who had entered the ranks, he explained in correspondence with company headquarters:

we are henceforth dealing with personnel who, while they don't have very well-formulated ideas about their duties, are on the other hand extremely up to date on their rights. On voyages where the layovers are numerous, we can hardly shift a straw. . . . To remediate this disaster, it will be necessary for anyone having anything to do with the Navy to ceaselessly battle the longoutdated regime of the Inscription maritime. ${ }^{35}$

And indeed, faced with militancy in motion, many Messageries captains adopted this strategy. Taking advantage of the statutory liminality of sailors and the gaping loophole available to any captain who could claim a threat to the security of navigation, they simply avoided ports altogether, pouncing instead on French warships along the route, and preventing the Inscription from fanning the fire of labour militancy. ${ }^{36}$

As China Line captains reacted to labour unrest by blocking the Inscription from acting in its capacity as an arbiter, they simultaneously leaned more heavily than ever on that very same Inscription to handle a host of other cases occurring outside French ports. Indeed, the company may have been attacking the institution on two fronts: starving it of influence over labour conflicts, while flooding it with petty administrative burdens. This, at least, was the fear of A. Jaquemart, the man who headed the Inscription in Saigon for much of the early twentieth century. In correspondence with Indochina's governor general, Jaquemart accused the consular network "East of Suez" of being squarely in the pocket of the Messageries. As he explained to the governor general, the unholy alliance between company agents and French consuls along the China Line may not have been enough to guarantee mass arrests of mutinous crews, but consuls were compensating captains by empowering them to disembark individual troublemakers in 
Saigon. Conveniently for the company, the Inscription footed the bill of legal proceedings, imprisonment and repatriation. What they could not solve in foreign ports and navy courts, in other words, Messageries captains brought to the French government in Saigon. As a result, Saigon's Inscription was ballooning into what Jaquemart described as the unmanageable "headquarters of a maritime arrondissement stretching from Suez to Yokohama". ${ }^{37}$ Offloading dissident individuals and petty offenders onto the Inscription when large-scale crackdowns were made impossible by foreign law codes, Messageries captains and agents continued exploiting the benefits of access to navy ships - and navy justice whenever they could claim a "threat to security of navigation". Here was an antilabour recipe composed of opportunism, expert navigation of state agencies and a cynical appraisal of the vagaries of maritime law.

But was this approach to combatting labour militancy systematic, merely opportunistic or, in a sense, a strategy built around maximising opportunism? After all, navy vessels were not always available, since their locations were contingent upon international relations and shrouded in secrecy. As for using the Inscription as a dumping ground for lesser offenders (or sailors who had wisely offended outside of French ports), eventually an angry administrator like Jaquemart could push back against the company. And indeed, for two decades, Jaquemart did just that, tirelessly working to expose the company's abuse of state resources and legal loopholes. ${ }^{38}$

\section{Colonial subjects and maritime labour}

For companies like the Messageries, perhaps the one truly systemic approach to combatting labour militancy arose from a system of hiring and rotating Asian and African workers, most of them subjects of the French and British Empires. The practice of manning Europe-to-Asia ships with Asian and African crews dated to the earliest trade routes; indeed, the very incident that inspired Grotius to theorise the "Free Sea" in the seventeenth century involved two European ships manned largely by inhabitants of the Indian Ocean littoral. ${ }^{39}$ In France, however, the practice had been disputed since the $1790 \mathrm{~s}$, when revolutionary law mandated that any flag-bearing ship have a crew of which 75 per cent were French nationals; for officers, the requirement rose to 100 per cent. Over the next century, steamship companies formed powerful political lobbies and chipped away at the requirements. By 1900, French citizens on flag-bearing ships operating in the Red Sea and Indian Ocean could legally constitute as little as 50 per cent of a crew. Unsurprisingly, the French-citizen workforce in Marseille detested the hiring of colonial subjects, and demands to abolish the practice, often framed in viscerally racist terms, were central planks of syndicalism from its origins. ${ }^{40}$

Like its British counterpart, the $P \& O$, the Messageries handled these criticisms adeptly. On its lines, directors made clear, the flow of traffic beyond Suez could be guaranteed only with contingents of African and Asian workers. Specifically, Messageries negotiators insisted that if Europeans worked in scorchinghot engine rooms during the Red Sea passage, they would die in droves. While 
maritime unions and their allies argued that employing "indigenous" sailors was unpatriotic and unsafe (their imputed cowardice and inability to communicate being posited as hazards during shipwrecks), even unionists accepted the premise that certain occupational hazards of maritime labour could only be resolved by hiring non-European workers. ${ }^{41}$ In a series of legal contortions, the most servile jobs aboard steamships were gradually bundled into this logic over the latter nineteenth century, so that Asians and Africans were overrepresented not only in brutally hot engine rooms, but also among deckhands and service "boys". Simultaneously, the Messageries and $P \& O$ endorsed laws restricting non-European sailors from working above certain latitudes. The stance was less counterintuitive than it appears, since by selectively ratifying the critique of non-European workers as untrustworthy safety hazards, these shipping giants of the Indian and Pacific Oceans effectively cut off competitors in the Atlantic and Mediterranean from the gold mine of low-wage workers recruited in colonial territories. ${ }^{42}$

The commercial advantages of hiring subject-workers cannot be overestimated. Compared to Europeans, they were paid less, lodged in smaller spaces and ate in kitchens with less equipment. Perhaps most importantly, they had no unions and little recourse to consuls and colonial branches of the Inscription. Thanks to the ease with which subject-workers could be recruited at layover ports along the route, moreover, captains frequently menaced mutinous sailors with replacement. Citizen sailors, who, in the case of the Messageries, came largely from Corsica and Provence, might enter the Inscription's database as early as 15 years old, and would contribute to a pension fund when they began work a few years later. By contrast, "indigenous" sailors were recruited in a far more informal manner, through "Serangs": brokers, translators and team leaders who coordinated relations between "indigenous" workers and the ship's officers. Subject-workers could be recruited at essentially any port of layover on the China Line, but for the Messageries, Aden and Hong Kong were particularly prominent hubs for recruiting Somali engine-room teams and Cantonese service workers ("boys" in colonial colloquialism). ${ }^{43}$ As captains occasionally admitted, recruiting workers with dubious papers and only the fuzziest of official identities gave the Messageries wide latitude in disembarking subject-workers, as well as how and, critically, where to handle their complaints. Captains could, for example, choose to disembark or punish a Somali sailor of the Red Sea in French Djibouti or British Aden, depending on what suited them best, by turning a blind eye to shoddy papers or casting doubt on legitimate ones. ${ }^{44}$ When the captain of the Messageries ship Cordillère became frustrated with his Indian engine-room team, meanwhile, he needed only a quick missive to contacts in the British government, and with a signature and a stamp, Indian subjects of the British Empire were transformed into subjects - for legal and punitive purposes at least - of a floating parcel of French land. ${ }^{45}$

Through the China Line ships of companies like the Messageries and $P \& O$, a pan-imperial procession of subject-workers flowed, leaving behind a shadowy presence in company records. Usually recorded with catchall categories (Arab, Malay, Chinese, Indian/Lascar, black, etc.), individuals' names generally went undisclosed in voyage reports and administrative reviews, unless they had died, 
deserted or been implicated in a controversy - a sharp contrast with European colleagues, whose names, basic biographies and employment history figured regularly in the voyage reports and administrative reviews that captains and port agents submitted to company headquarters in Europe. The superiors reading those reviews never scolded their subalterns for careless bookkeeping. Indeed, relegating subject-workers to the administrative shadows was unspoken company policy. ${ }^{46}$ The sketchiness of subject-workers' administrative status was reflected in the racial tropes with which they were evaluated. Racial tropes played important roles in justifying decisions over whom to hire, fire or transfer, but these tropes, steeped in "colonial common sense", were, of course, utterly manipulable. ${ }^{47}$ Often enough, groups of workers who had been lauded for their race's ostensible docility and adaptability were fired for their race's impudence and stubbornness, only to be replaced by a new group of racialised workers, now deemed more docile and adaptable.

As the Messageries rode the wave of French imperial expansion, what began as a legal allowance to hire a few "indigenous" Red Sea workers for blistering engine rooms transformed into a sprawling network of labour recruitment, defined by a multiplicity of contracts, terms and paperwork regimes. To maintain their right to recruit imperial subjects, lines like the Messageries needed to argue that only subject-workers were sturdy and reliable enough for the gruelling labour of the steamship. To expand outsourced recruitment to a scale beyond any government's regulatory powers, however, subject-workers had to be portrayed as incompatible with stable, centralized recruitment systems; one group of subject-workers, in other words, would always have to be replaced and replenished by another. ${ }^{48}$

European workers, then, were not alone in fearing replacement by "natives". Those indispensable "natives" were utterly replaceable, too. Writing in 1919, after years of service, including on Messageries ships that spent the war dodging U-boats, the leader of an Arab engine-room team testified to the shock of that realisation. Pleading with Messageries bosses after learning that he and his team would be replaced by a Chinese crew, he wrote to his captain in phonetic French:

in recompense and gratitude for our services, the company finds nothing better than to transform its crew and my command, to replace us, the Arabs, with Chinese. We are, it's true, children of the sun, but we have nonetheless a heart to love, a conscience to judge, and a spirit to appreciate, and I refuse to believe, my Captain, that your noble sentiments of humanity and equitable justice would be able to act in concert with the company for such procedures. . . ${ }^{49}$

Whatever the captain's feelings regarding the heartfelt plea, bosses in Marseille remained unmoved. "Let the serang [team-leader] of the Arabs know", a superior wrote in response, "that we don't have to explain our reasons for embarking in his place a team of Chinese coalers". Indeed, not having to explain was one of the greatest luxuries afforded to the Messageries by its globalized labour network.

Their system of racialising the workforce and setting it into near-constant rotation afforded the Messageries more than just bottom-line savings and flexibility 
in hiring and firing. The practice also prevented meaningful relationships from developing between "European" and "Indigenous" crewmembers - relationships with the potential to transmit labour militancy between citizens and subjects. Officially, the unions castigated the employment of imperial subject-workers and denigrated those workers themselves (it took decades before the unions experimented with advocating equal pay and benefits), but there were exceptions on the ground, or rather, on the deck. At times, workers reached beyond the colour lines. In 1910, one China Line captain watched this unfold, when the leader of his Arab engineroom team issued a protest that included the line, "I lead a team of men and I don't even have the wages of a low-down European coaler who doesn't know how to do anything other than pour oil into a bucket" ${ }^{50}$ As the captain investigated further, he found troubling implications in the reclamation, which struck him as anything but isolated. "We must never lose sight", he wrote to superiors, "of the fact that these men are in contact with the workers of the Workshops and the European coalers who, according to intelligence given to me by the mechanics, seek to catechize them and push them into militancy".51 The company had good reason to fear sociality across racial boundaries, since their profitability relied upon racially stratified wages and working conditions. Contact between "European" and "indigenous" personnel could lead to pan-racial agitation for workplace improvements. For the Messageries, then, ensuring the failure of labour's "catechism" meant shuffling subject-workers as often as possible in a system of racialised substitution. The workforce was thus endowed with a permanent racial Other whose race was ever-changing.

During the First World War, as hundreds of thousands of French merchant mariners were drawn into the war effort, the Messageries accelerated efforts to hire Africans and Asians. For the first time, though, these subject-workers possessed the leverage to win substantial increases in wages and benefits, thanks to the scarcity of labour and the exceptional risks incurred by their wartime service. Messageries bosses may have feared that their fabled goose was running out of golden eggs, but with few options available to them, they stuck to their playbook of segregating and rotating the workforce by race. By the end of 1915, for instance, company directors in Marseille and Paris launched plans to replace more of the "European element" with an "Indigenous element". As the top technical advisor in the Messageries' Central Administration explained in a widely circulated memo, "given the difficulties created by the Unions [and] the less-and-less easy recruitment of European personnel, it would be good to take advantage of the conditions opened up by the war". To this end, European personnel would be phased out of new ships as much as possible; "Tonkinese" would be sought for the restaurants and cabin service; "Japanese, preferably", would replace the Chinese workers; and increasingly troublesome "Arab coalers" would be replaced by Indians, deemed "more intelligent than the Arabs". ${ }^{52}$ When those Indian coalers outstayed their welcome in the Messageries roster, they were labelled weak and irritable, and Marseille sent its port agents instructions to replace them with Arabs, Chinese or Japanese. ${ }^{53}$ Similar processes were playing out in British companies along the China Line. ${ }^{54}$ 
When the war ended, mass-mobilisation of organised labour led France to become the world's only country to extend eight-hour workday legislation to its maritime sector. With striking ships piling up in French ports along the China Line, a chorus of captains and company agents vented unprecedented disdain for their European personnel and called for increasing recruitment of Asians and Africans. ${ }^{55}$ Before the rise of the maritime unions, such calls had been based on the unbearable conditions of steamship engine rooms; by the interwar, they were based on the unbearable character of the unionised sailor.

\section{Conclusion}

Maritime labour militancy extended well beyond the dockyards of major European port cities. A mobile proletariat, merchant mariners brought militancy with them to sea. To quell labour activism along its trans-Suez routes, the Messageries mobilised a vast network of port agents, consuls, captains, lobbyists, bureaucrats and police. In the struggles that ensued, maritime workers proved remarkably capable of outlasting their bosses and outmanoeuvring them in the interstices of imperial sovereignty. The mutinous mariners of the early 20th century took advantage of the fact that their worksite was a bundle of often-contradictory roles. After all, every steamship was a mobile coal plant for some and a floating luxury hotel for others; a profit-generating machine for private capital and an instrument of state power; a world unto itself and an emissary hopping from port to port with little regard for imperial boundaries. In such a setting, the conditions of possibility for workers were set by the politics of mobility and the peculiar nature of governance in the in-between spaces of empires. Ultimately, the ingenuity of steamship workers met its match in the company's racialisation and rotation of an informal workforce. By the mid-twentieth century, when maritime unions attempted interracial solidarity in earnest, new threats to organised labour were already appearing, not least among them automation. ${ }^{56}$

\section{Notes}

1 M. R. Loew, Les Dockers de Marseille (L'Arbresle: Économie et Humanisme, 1946); W. Sewell, "Uneven Development, the Autonomy of Politics and the Dockworkers of Nineteenth-century Marseille," American Historical Review 93, no. 3 (June 1988): 604-37; Pacini and Pons, Dockers à Marseille (Paris: Payot, 1996); B. Marnot, Les Villes portuaires maritimes en France, XIXe-XXI siècle (Paris: Armand Colin, 2015); J. Barzman, "Dock Labour in Le Havre 1790-1970," in Dock Workers: International Explorations in Comparative Labour History, 1790-1970, ed. S. Davies, C. Davis, D. de Vries, L. Heerma van Voss, L. Hesselink, and K. Weinhauer (New York: Routledge, 2017). Maritime historians have been urged to look beyond the docks more recently in M. Dusinberre and R. Wenzlhuemer, "Editorial - Being in Transit: Ships and Global Incompatibilities," Journal of Global History 11, no. 2 (2016): 155-62; Chaline, KnabDelumeau, and Kowalski, "Le navire à la mer," Revue d'histoire maritime 25 (2019).

2 Ronan Viaud, Le syndicalisme maritime français. Les organisations, les hommes, les luttes (1890-1950) (Rennes: Presses universitaires de Rennes, 2015); J. Charles-Roux, "Les grèves et l'inscription maritime," Revue des deux mondes. Tome 54 (NovemberDecember 1909): 124-46. 
3 Dusinberre and Wenzlhuemer, "Editorial - Being in Transit"; J. W. Konvitz, "The Crises of Atlantic Port Cities, 1880-1920," Comparative Studies in Society and History 36, no. 2 (1994): 293-318; A. Vigarie, Ports de commerce et vie littorale (Paris: Hachette, 1979).

4 Michel Foucault, "Des espaces autres," Empan 54, no. 2 (2004): 12-19.

5 See R. Mawani, Across Oceans of Law: The Komagata Maru and Jurisdiction in the Time of Empire (Durham, NC: Duke University Press, 2018); William Walters, "Migration, Vehicles, and Politics: Three theses on Viapolitics," European Journal of Social Theory 18, no. 4 (2015): 469-88.

6 Via layovers in Naples, Port-Saïd, Aden or Djibouti, Bombay or Colombo, Singapore, Saigon, Hong Kong, Shanghai and Kobe.

7 Future research may uncover a second domain of strategic (as opposed to opportunistic) anti-labour practice in the Messageries' collaboration with the British Shipping Federation. As the co-editor of this volume, Alessandro Saluppo discovered the Messageries reacted to a massive seamen's strike in 1902 by writing to the federation. The founding of the Comité Central des Armateurs Français the next year suggests that the Messageries was seriously considering pooling resources with foreign firms, sharing blacklists and forming a transnational body of professional strikebreakers. See Alessandro Saluppo, "Strikebreaking and Anti-Unionism on the Waterfront: The Shipping Federation, 1890-1914," European History Quarterly 49, no. 4 (2019): 570-96.

$8 \mathrm{M}$. Beneron-Couvenhes, Les Messageries maritimes. L'essor d'une grande compagnie de navigation française, 1851-1894 (Paris: Presses de 1'Université Paris-Sorbonne, 2007); P. Ramona, Paquebots vers l'Orient (Paris: Alan Sutton, 2013); P. Bois, Le grand siècle des Messageries maritimes (Marseille: Chambre de commerce \& de l'industrie de Marseille-Provence, 1986).

9 Berneron-Couvenhes, Les Messageries maritimes, 406-7.

10 Le Journal des transports: revue internationale des chemins de fer et de navigation 14 , no. 14 (1891): 417.

11 Today, the Messageries survives in the Marseille-headquartered container-shipping giant, CMA-CGM; the world's third largest, into which it was bundled in the 1970s. "An Entrepreneurial Adventure," CMA-CGM Group, accessed July 3, 2020, www. cmacgm-group.com/en/group/history/entrepreneurial-adventure.

12 Jules Verne, Une ville flottante (Paris: Hetzel, 1871).

13 For a discussion of this distinction, see Naina Manjrekar, "Violent and Not Quite Modern?': Lascars and Everyday Resistance Across the Sail-Steam Divide," Labour History: A Journal of Labour and Social History 116 (2019): 29-55; see also M. H. Renaut, "L'Histoire par les Lois: Trois siècles d'évolution dans la repression des fautes disciplinaires de la marine marchande," Revue historique de droit français et étranger 80 , no. 1 (2002): 23-56.

14 "Makeshift" conveys the French phrase, équipage de fortune.

15 Voyage Report of Commandant Cassanova, China Line, 1 September 1909, Messageries Maritimes (MM) 86, Dossier Voyage Reports of the Caledonien (1908-17), Chambre de Commerce \& de l'industrie Marseille-Provence (CCIMP), Marseille, France.

16 Nowhere did this apply more than in the Suez Canal. See Valeska Huber, Channeling Mobilities: Migration and Globalisation in the Suez Canal Region and Beyond, 1869-1914 (Cambridge: Cambridge University Press, 2013).

17 Ibid.

18 Voyage Report 22, China Line, Commandant Tivolle, 25 October 1912, MM 86, Dossier Calédonien Voyage Reports (1908-1917), CCIMP, Marseille, France. The term apache almost certainly derived from the North American Apache Indians; see Michelle Perrot, "Dans la France de la Belle Époque, les 'Apaches,' premières bandes de jeunes," La Lettre de l'enfance et de l'adolescence 67, no. 1 (2007): 71-78.

19 Voyage Report 22, China Line, Commandant Tivolle, 25 October 1912, MM 86, Dossier Calédonien Voyage Reports (1908-1917), CCIMP, Marseille, France. 
20 The official police presence onboard Messageries ships was limited to officers (the company occasionally hired private detectives to investigate trafficking, and probably militancy as well, though I have found no record of the latter). Officers, especially the capitaine d'armes were entrusted with surveillance and police work, as was, to a lesser extent, the maître d'équipage, or boatswain. Even when acting in a police capacity officers' power to repress rebellious workers was limited by a determination not to attract unwanted attention from paying passengers and the fact that they rarely outnumbered the workers who they would be repressing (neither limit applied to port police). The thin police presence onboard such passenger steamships was reflected in remarkably frequent evasions of traveling convicts and soldiers.

21 Inquiry by Commandant Froment, 19 June 1913, MM 86, Dossier Calédonien (1908-17), "Incident à Colombo," CCIMP, Marseille, France.

22 Letter from the General Consul, 26 February 1913, MM 86, Dossier Calédonien (1908-17), "Incident à Colombo," CCIMP, Marseille, France.

23 "Legality of Action by Colonial Govt in case of mutiny tc. Arising on Foreign Ship lying in Colonial Port," March 1906, Foreign Office (FO) 372/28/59, The National Archives of the United Kingdom (TNA), London, UK.

24 "Mutiny of Chinese crew of SS Epsom at Naples and their Repatriation," March 1906, FO 369/25/32, TNA, London, UK.

25 “Attorney General to Lt. Governor," 3 March 1906, FO 372/28/59, TNA, London, UK.

26 “Ashmore to Daniels," 23 March 1906, FO 372/28/59, TNA, London, UK.

27 "Minute by Davidson," 9 March 1905, FO 372/28/59, TNA, London, UK.

28 "Lt. Governor - AMS," 27 March 1906, FO 372/28/59, p. 19, TNA, London, UK.

29 "Re. the Warrant to arrest the crew of the Russian S.S. 'Grigory Moerch'," 2 April 1906 , FO 372/28/59, TNA, London, UK.

30 It would take another three decades, however, for the draconian disciplinary code to be fully overhauled. Renaut, "L'Histoire par les Lois: Trois siècles d'évolution dans la repression des fautes disciplinaires de la marine marchande," 23-56.

31 Hence for instance the pension that Inscription sailors received. Viaud, Le Syndicalisme maritime français, 13-20.

32 Voyage Report 21, Commandant Schmidt, China Line, 14 October 1900, MM 559, Dossier Yarra Voyage Reports (1893-1907), CCIMP, Marseille, France.

33 Ibid.

34 Ibid.

35 Voyage Report 19, Commandant Bruno, Madagascar Line, 14 September 1909, MM 551, Dossier Voyage Reports Yarra (1908-17), CCIMP, Marseille, France.

36 Voyage Report 8, Australia Line, Commandant Melber, April 1911, MM 86, Dossier Voyage Reports Caledonien (1908-17), CCIMP, Marseille, France; Voyage Report 22 , China Line, Commandant Tivolle, 25 October 1912, MM 6, Dossier Voyage Reports Amazone (1919-20), CCIMP, Marseille, France; "Commandant Lapousse, China Line," 17 April 1920, MM 20, Dossier Andre Lebon (1919-21), CCIMP, Marseille, France; Voyage Report 11, China Line, Commandant Cousin, 19 October 1920, MM 20, Dossier Andre Lebon (1919-21), CCIMP, Marseille, France.

37 "Jaquemart (Chef du service maritime) au Gouverneur-général à Hanoi," 23 February 1910, IA/Dossier 2909, Saigon Inscription Maritime (1907-1913), National Archives of Vietnam Center 2, Ho Chi Minh City, Vietnam.

38 Jaquemart's files from the Saigon Inscription Maritime span IA/Dossiers 2909, 2808, and 27202 of the National Archives of Vietnam Center 2, Ho Chi Minh City, Vietnam.

39 Peter Borschberg, "The Seizure of the Sta. Catarina Revisited: The Portuguese Empire in Asia, VOC Politics and the Origins of the Dutch-Johor Alliance (1602-1616)," Journal of Southeast Asian Studies 33, no. 1 (2002): 42.

40 Viaud, Le Syndicalisme maritime français, 32-40.

41 Gopalan Balachandran, Globalizing Labour? Indian Seafarers and World Shipping, c. 1870-1945 (Oxford: Oxford University Press, 2012), 122-30. A typical example of the 
discourse can be found in J. Beaumont, Ships - and People (London: Geoffrey Bles, 1921), 20-21.

42 Berneron-Couvenhes, Les Messageries maritimes, 165-67, 490-92; Balachandran, Globalizing Labour? 126-28.

43 Paul Bonnetain and Louis Tillier, Histoire d'un paquebot (Paris: Quantin, 1894), 70-81.

44 The incoherence of Red Sea paperwork regimes is on vivid display in the Centre d'archives diplomatiques de Nantes' foreign consul files for Aden and Port-Saïd. See also R.I. Lawless, "Recruitment and Regulation: Migration for Employment of 'Adenese' Seamen in the Late Nineteenth and Early Twentieth Centuries," in New Arabian Studies, ed. R. L. Bidwell, G. Rex Smith, and J. R. Smart (Exeter: University of Exeter Press, 1994), 75-95.

45 "Note of 7 Feb. 1918". 7 February 1918, MM 152, Dossier Diverse Correspondence Cordillère (1912-20), CCIMP, Marseille, France.

46 At the time of research, voyage reports for Messageries ships were held by two archival centers: the Association French Lines in Le Havre and the Chambre de commerce et de l'industrie Marseille-Provence in Marseille.

47 Ann Stoler, Along the Archival Grain: Epistemic Anxieties and Colonial Common Sense (Princeton, NJ: Princeton University Press, 2009).

48 "La Ciotat" December 1919, MM 59, Dossier Diverse Correspondence Australien (1916-18), CCIMP, Marseille, France; see also, "Indiens, Arabes, Chinois. Amazone," 25 January 1918, MM 5, Dossier Diverse Correspondence Amazone (1912-18), CCIMP, Marseille, France.

49 “Lettre d'un surang," 12 December 1919, MM 6, Dossier Diverse Correspondance, Amazone (1919-1920), CCIMP, Marseille, France.

50 "Lettre de réclamation d'un surang Arabe," 17 March 1910, MM 165, Dossier Diverse Correspondence Djemnah (1903-1918), CCIMP, Marseille, France. See also, Voyage Report 17, 9 November 1917, MM 152, Dossier Voyage Reports Cordillère (19121920), CCIMP, Marseille, France.

51 "Lettre de réclamation d'un surang Arabe," 17 March 1910, MM 165, Dossier Diverse Correspondence, Djemnah 1903-1918, CCIMP, Marseille, France.

52 "Essais de l'Andre Lebon, Note sur le personnel subalterne," 5 December 1915, MM 19, Dossier Diverse Correspondence Andre Lebon, CCIMP, Marseille, France.

53 "Indiens, Arabes, Chinois. Amazone," September 1918, MM 6, Dossier Diverse Correspondence, Amazone, CCIMP, Marseille, France.

54 See, for example, TNA Ministry of Transport (MT) 23/785; TNA MT 23/621; TNA Home Office 45/13392

55 Voyage Report 10, Commandant Cochery, China Line, 31 May 1920, MM 129, "Chili" (1917-1922), Dossier “Indiens," CCIMP, Marseille, France.

56 For perspective, one of the world's largest container ships, the Jules Verne, belongs to the Messageries' successor, CMA-CGM. Longer than the Empire State Building, the vessel is operated by a mere 26 people; eight French officers and 16 Filipino crewmembers. “'Jules Verne', le plus gros porte-conteneurs du monde," Le Parisien, June 5, 2013. 